\title{
Magnesium Composite Materials Prepared by Extrusion of Chemically Treated Powders
}

\author{
Drahomír Dvorský, Jiř́i Kubásek, Dalibor Vojtěch
}

University of Chemistry and Technology Prague, Faculty of Chemical Technology, Department of Metals and Corrosion Engineering, Technická 516628 Praha 6 - Dejvice, Czech Republic, Email: dvorskyd@vscht.cz

\begin{abstract}
This paper is focused on the preparation of the magnesium composite materials by extrusion of the chemically treated powders. Microstructures with partially preserved borders between particles containing specific elements depending on the preparation method were created by extrusion. Compressive mechanical properties of extruded chemically treated powders were similar to material prepared from atomized powder. The corrosion rate was reduced by three times in the case of chemically treated powder compared to the pure Mg. Ignition temperature of the chemically treated powder increased by up to $200{ }^{\circ} \mathrm{C}$ compared to the atomized powder, while ignition temperatures of the extruded samples were only slightly improved.
\end{abstract}

Keywords: Composite material, corrosion, powder metallurgy, extrusion, ignition temperature.

\section{Introduction}

Magnesium is a desirable material for an automotive and aviation industry due to its low density and relatively good mechanical properties [1], [2]. Its utilization is limited due to the poor corrosion resistance and loose of mechanical properties at elevated temperatures. Also, the preparation of magnesium is problematic due to the high affinity of magnesium to oxygen [3]. Therefore, it has to be melted under a protective atmosphere of $\mathrm{SF}_{6}$ for example [4], [5], [6], [7]. The protective layer of $\mathrm{MgF}_{2}$ is then created on the surface of the melt. Otherwise, the thermal stability of $\mathrm{MgF}_{2}$ on air is only up to $800{ }^{\circ} \mathrm{C}$, where it starts to convert to $\mathrm{MgO}$ [8]. Alloys with improved resistance to oxidation were developed especially due to the cancelation of the ban for magnesium alloys in aircraft cabins by the Federal Aviation Administration (FAA) [1], [9]. Proposed materials have to pass the ignition test, where they can ignite only after a certain temperature. WE43 alloy was approved by the FAA, while AZ91 failed those tests [1], [10], [7]. Therefore, new alloys and methods of preparation were published in order to provide material suitable for this application, as it would reduce the mass of aircraft by up to $30 \%$ and subsequently reduce the emission of $\mathrm{CO}_{2}$ [10], [11].

Another utilization of magnesium is for biodegradable implants due to its good biocompatibility and mechanical properties which are close to the bone tissue and therefore the problem with stress shielding effect is eliminated [12], [13]. Among the greatest disadvantages of the magnesium materials is the high corrosion rate which is associated with hydrogen release. Improving corrosion resistance by alloying is effective, however, the biocompatibility of such implant might be reduced due to the alloying elements. Moreover, magnesium is sensitive to impurities such as $\mathrm{Fe}, \mathrm{Ni}, \mathrm{Cu}$, and $\mathrm{Co}$ and if their concentration exceeds their limits (170 ppm for Fe) there is danger of excessive corrosion rate or localized corrosion [14], [15]. Corrosion rate might be reduced by the creation of composite materials with the low soluble reinforcement. Composite materials are usually also characterised by improved mechanical properties.

Another method for improving the corrosion resistance of magnesium alloys is by using coatings [16],
[17], [18]. There are several possible and effective coatings for magnesium biodegradable implants, for example, fluoride conversion coating [18]. This coating is based on the resistance of magnesium in hydrofluoric acid and low solubility of $\mathrm{MgF}_{2}$. Such coating is very thin ( 0.1 to $\left.4 \mu \mathrm{m}\right)$ and with good adhesive strength (33 to $43 \mathrm{MPa}$ ) [19], [20], [21]. According to the cytotoxicity tests, the $\mathrm{MgF}_{2}$ coating is fully biocompatible and it was even tested on the animals with positive results [20], [21], [22], [23] $\mathrm{MgF}_{2}$ coating can reduce the corrosion rate on the tenth of the original value [18]. However, there is danger of disturbing the surface layer and as a consequence, localized corrosion would appear.

The danger of disturbing the surface layer can be reduced by the creation of a continuous network of $\mathrm{MgF}_{2}$ [24]. Nevertheless, mechanical properties are not high enough after processing by spark plasma sintering. Preparation of such materials is based on the processing of chemically treated powders. Magnesium powder is immersed in hydrofluoric acid and thus a surface layer of $\mathrm{MgF}_{2}$ is created around each particle. Such a coating is protective against the oxidation of the powder, which might be useful for long-term storage of magnesium powders. However, materials prepared from the treated powder might exert different properties.

Extrusion is a common method for processing of magnesium materials based on thermomechanical processing. Products prepared by extrusion exert good mechanical properties due to the recrystallization process and finegrained structure [25]. Fine grains can be especially gained by the powder metallurgy route and they also improve corrosion properties [26], [27]. The powder of the material is made by atomization, which is associated with rapid cooling and therefore particles with fine grains and oversaturated solid solutions are created. Nevertheless, magnesium tends to form a texture after deformation and it may result in anisotropy of mechanical properties.

In this work, a preprocessed magnesium powder was extruded at $400{ }^{\circ} \mathrm{C}$ in order to obtain a composite material containing $\mathrm{MgF}_{2}$, which would decrease a corrosion rate, while mechanical properties would be improved. Also, ignition properties of the chemically treated powders and prepared extruded materials were tested. 


\section{Materials and methods}

\subsection{Powder treatment}

Magnesium commercial atomized powder with impurities measured by ICP-MS (Elan DRC-e) (90 ppm Fe, 10 ppm $\mathrm{Cu}, 20 \mathrm{ppm} \mathrm{Ni}$ ) was boiled in $200 \mathrm{~g} / \mathrm{l} \mathrm{NaOH}$ for 2 hours. The powder was then rinsed with distilled water and ethanol and desiccated at $50{ }^{\circ} \mathrm{C}$. The powder was afterward immersed in $40 \% \mathrm{HF}$ and stirred for 24 hours. After immersion, the powder was again rinsed with distilled water and ethanol and desiccated at $50{ }^{\circ} \mathrm{C}$. Another powder was just immersed in the HF without pre-boiling it in $\mathrm{NaOH}$.

\subsection{Compacting}

Magnesium chemically treated powders were then processed cold-pressed at $80 \mathrm{kN}$ for 2 minutes. The green compacts were subsequently extruded at $400{ }^{\circ} \mathrm{C}$ with extrusion ratio 10 and extrusion rate of $5 \mathrm{~mm} / \mathrm{min}$.

\subsection{Microstructure}

The microstructures of the compact materials were characterized by electron scanning microscopy (SEM TescanVEGA3) with energy dispersion spectrometry (EDS, AZtec). Samples were ground on SiC grinding papers (P80-P2500) and polished on diamond paste D3, D2, and D0.7. The final polishing was done on Etosil E.

\subsection{Mechanical properties}

Compressive tests were performed on LabTest 5.250SP1-VM at room temperature. The specimens for compressive tests were cylindrical with $5 \mathrm{~mm}$ in diameter and $7 \mathrm{~mm}$ high. The strain rate of $0.001 \mathrm{~s}^{-1}$ was used. Basic mechanical data were evaluated.

\subsection{Immersion test}

Immersion tests were performed in simulated body fluid (SBF) at $37{ }^{\circ} \mathrm{C}$ for 14 days. The ratio of solution volume to the surface area was $100 \mathrm{ml} \cdot \mathrm{cm}^{-2}$. After 14 days, samples were removed from the immersion solution and were rinsed in distilled water and dried. The corrosion products were removed by the solution of $200 \mathrm{~g} \cdot \mathrm{l}^{-1} \mathrm{CrO}_{3}$, $10 \mathrm{~g} \cdot \mathrm{l}^{-1} \mathrm{AgNO}_{3}, 20 \mathrm{~g} \cdot \mathrm{l}^{-1} \mathrm{Ba}\left(\mathrm{NO}_{3}\right)_{2}$ at room temperature. Samples were then dried and weighed. The corrosion rate was calculated from weight changes.

\subsection{Ignition test}

The surfaces of samples with dimensions $15 \times 15 \times 5$ $\mathrm{mm}$ were finished by grinding on the paper P1200. Subsequently, samples were put in the $\mathrm{Al}_{2} \mathrm{O}_{3}$ crucible which was inserted into the resistance furnace. One thermocouple was in direct contact with the sample and the other one was in the middle of the crucible. There was a tube with the airflow on the other side of the crucible. Technical air with airflow of $100 \mathrm{l} / \mathrm{h}$ was used to supply the crucible with oxygen. The heat rate of the furnace was set to $35^{\circ} \mathrm{C} / \mathrm{min}$. The temperature increased with time until the temperature rose rapidly due to the ignition of the sample. Each sample was measured three times.

\section{Results and discussion}

\subsection{Microstructure}

Atomized powder of pure magnesium was characterized with round-shaped particles with a diameter ranging from 10 to $250 \mu \mathrm{m}$. The grain size of the powder did not exceed $50 \mu \mathrm{m}$. Immersion of powder in HF leads to the creation of homogeneous coating of $\mathrm{MgF}_{2}$. In order to create thicker coating atomized powder was boiled in $\mathrm{NaOH}$ for 2 hours for the creation of $\operatorname{Mg}(\mathrm{OH})_{2}$ coating which was subsequently converted in hydrofluoric acid into $\mathrm{MgF}_{2}$ thick coating as was presented in the previous work [28].
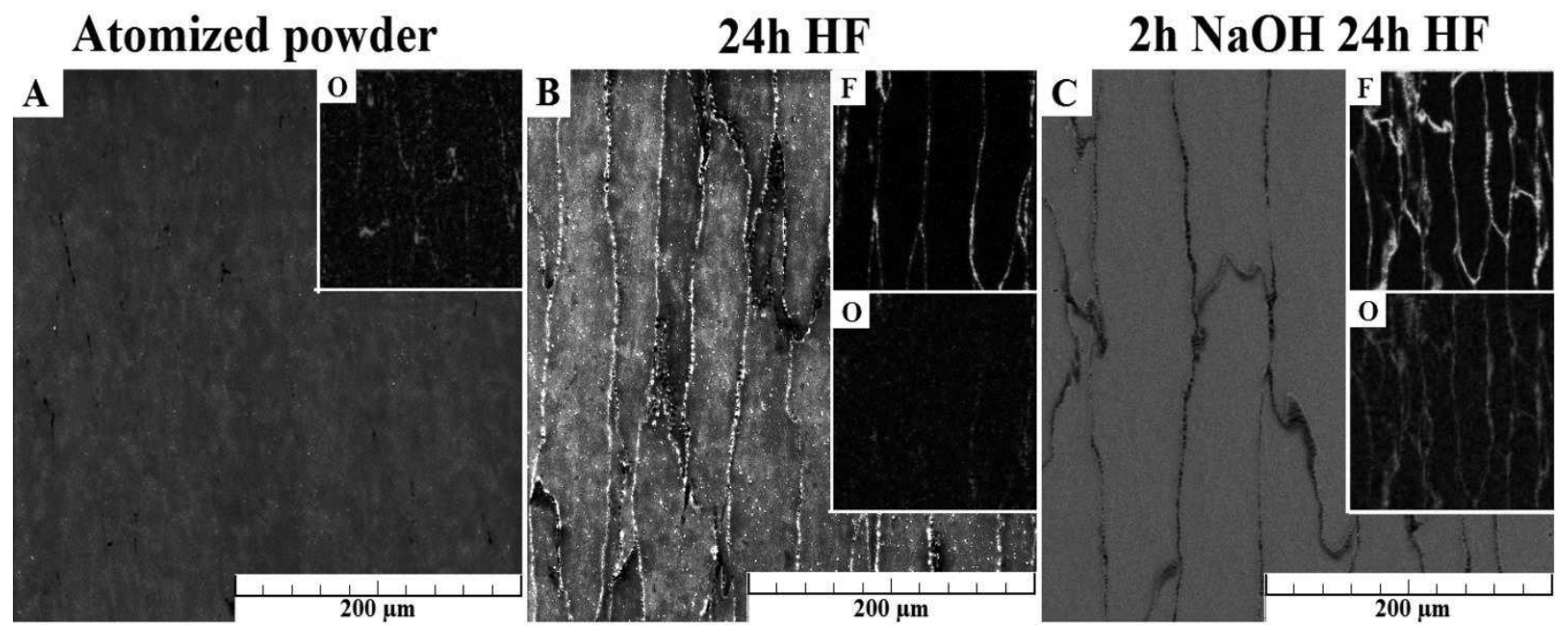

Fig. 1 The microstructure (SEM) and EDS analysis of $F$ and $O$ of extruded A) $M g, B) M g-H F, C) M g-N a O H-H F$.

Chemically treated powders were cold-pressed and extruded. The final microstructures are shown in Fig.1. Material prepared from the as received atomized magnesium powder were characterized by oxide rich regions around deformed particles of original powder (Fig. 1A). An increased concentration of oxide is due to the presence of the oxide on the surface of the original atomized pow- 
der. The total amount of oxygen measured by EDS analysis of the surface of the sample was about $1.5 \pm$ 0.1 wt.\%. On the other hand, the bare immersion of magnesium powder in HF leads to the microstructure in Fig.1B which was basically oxide-free $(0.2 \pm 0.1 \mathrm{wt} . \%)$. Instead of the oxide rich regions, there were fluoride-rich regions around each particle deformed in the direction of the extrusion. The low extrusion ratio was probably the reason behind partial preservation of original borders between particles. According to the previous results, better adhesion strength and lower solubility of $\mathrm{MgF}_{2}$ compared to the $\mathrm{MgO}$ can result in better performance of this material [24]. Pre-boiling of the powder in $\mathrm{NaOH}$ leads to the very thick borders between deformed particles, which consist of $\mathrm{MgF}_{2}$ and $\mathrm{MgO}$ (Fig.1C). $\mathrm{MgO}$ was created during extrusion as the residual $\mathrm{Mg}(\mathrm{OH})_{2}$ decomposed into $\mathrm{MgO}$ at elevated temperature. The total amount of oxygen in the structure was therefore increased to $2.7 \pm$ 0.2 wt.\%.

\subsection{Mechanical properties}

The compressive properties of the prepared samples together with other properties are summarized in Tab. 1. One can see that in the case of the pure magnesium compressive properties were not affected by the magnesium fluoride. On the other hand, boiling in $\mathrm{NaOH}$ and subsequent immersion in HF caused a slight increase of compressive yield strength, however, also a decrease of ultimate compressive strength and plasticity probably due to the fragile $\mathrm{MgO}$ created during extrusion from the residual $\mathrm{Mg}(\mathrm{OH})_{2}$. Nevertheless, the compressive mechanical properties are still much higher than if the material is prepared by spark plasma sintering (SPS) [24], [28].

Tab. 1 Compressive and corrosion properties with ignition temperatures of powders and compact samples.

\begin{tabular}{|c|c|c|c|c|c|c|}
\hline & CYS $[\mathrm{MPa}]$ & UCS $[\mathrm{MPa}]$ & $\mathrm{D}[\%]$ & $\mathrm{v}_{\text {cor }}[\mathrm{mm} / \mathrm{y}]$ & $\mathrm{T}_{\mathrm{ig}}\left[{ }^{\circ} \mathrm{C}\right]$ & $\mathrm{T}_{\text {ig }}$ powder $\left[{ }^{\circ} \mathrm{C}\right]$ \\
\hline $\mathrm{Mg}$ & $97 \pm 4$ & $315 \pm 8$ & $12.1 \pm 0.9$ & $3.129 \pm 0.315$ & $642 \pm 6$ & $585 \pm 5$ \\
\hline $\mathrm{Mg} \mathrm{HF}$ & $99 \pm 2$ & $321 \pm 6$ & $12.9 \pm 1.6$ & $1.031 \pm 0.166$ & $675 \pm 8$ & $790 \pm 6$ \\
\hline $\mathrm{Mg} \mathrm{NaOH} \mathrm{HF}$ & $109 \pm 2$ & $260 \pm 10$ & $9.3 \pm 2.1$ & $1.239 \pm 0.231$ & $673 \pm 7$ & $675 \pm 6$ \\
\hline
\end{tabular}

\subsection{Corrosion properties}

The corrosion behavior was studied in SBF for 14 days at $37^{\circ} \mathrm{C}$ and the measured corrosion rates calculated form the weight changes are summarized in Tab. 1. One can see a rapid decrease in corrosion rate of chemically treated extruded samples due to the creation of the barriers of hardly soluble $\mathrm{MgF}_{2}$ around each deformed particle. These barriers are across the whole sample and, therefore, they effectively reduce the corrosion rate even after breaching the initial barrier as the corrosion front gets through the material it is afterward slowed down on another barrier similarly as it was presented in the previous work for the materials prepared by SPS [24], [28]. The corrosion rate of magnesium with thicker $\mathrm{MgF}_{2}$ barriers is slightly increased due to the presence of $\mathrm{MgO}$ in the structure as it might be dissolved more easily than $\mathrm{MgF}_{2}$. However, materials prepared by SPS exerted better corrosion resistance than after extrusion as the borders around each particle are better preserved and not partially broken like after extrusion.

\subsection{Ignition test}

Ignition tests were studied on powders as well as on compact samples in the furnace with the input of technical air. Ignition temperatures are summarized in Tab. 1. Atomized magnesium powder was characterised with very low ignition temperature of $585{ }^{\circ} \mathrm{C}$, which is associated with the increased surface of the powder particles compared to the bulk material. Magnesium powders are therefore extremely dangerous in the means of fire safety. Individual particles have to be immersed in the hydrofluoric acid in order to protect magnesium powder from oxidation as the $\mathrm{MgF}_{2}$ coating will be created around each particle. $\mathrm{MgF}_{2}$ coating works similarly as the surface layer of $\mathrm{MgF}_{2}$ created on the melt during melting under $\mathrm{SF}_{6}$ atmosphere. Nevertheless, such coating decomposes on air on temperatures above $750{ }^{\circ} \mathrm{C}$ [8]. One can see that such a coating leads to the significant improvement of ignition temperature by up to $200{ }^{\circ} \mathrm{C}$. Similar ignition temperature to this material has for example, bulk material of $\mathrm{Mg}-1.5 \mathrm{Nd}$ alloy $\left(780^{\circ} \mathrm{C}\right)$ [3] However, powders are more prone to burning than bulk materials. Pre-boiling of the powder in $\mathrm{NaOH}$ before immersion in $\mathrm{HF}$ only increased the ignition temperature almost by $100{ }^{\circ} \mathrm{C}$. Less efficiency of this method is due to the oxide residues which probably deteriorate the effectiveness of $\mathrm{MgF}_{2}$ coating. The differences of the materials after extrusion are not so significant as in the form of powders. This is due to the uncovered areas of the magnesium, where $\mathrm{MgF}_{2}$ covers only small portion of the total surface of the sample. Still, extruded materials prepared from chemically treated powders exerted slightly higher ignition temperatures than material prepared from atomized powder.

\section{Conclusion}

Composite materials with $\mathrm{MgF}_{2}$ reinforcement were successfully created by extrusion. All materials were characterised by deformed particles in the extrusion direction. Borders between original atomized particles were still distinguishable and they were rich on the specific element depending on the preparation method. Compressive properties of pure magnesium powder were not negatively affected by bare immersion of the powder in HF. Pre-boiling in $\mathrm{NaOH}$ leads to the decrease of plasticity. Both preparation methods also decreased corrosion rate three times compared to the pure $\mathrm{Mg}$. Preboiling the powder in $\mathrm{NaOH}$ lead to the creation of $\mathrm{MgO}$ which slightly reduced the corrosion resistance compared to the bare immersion in HF. Chemically treated powders 
exerted significantly increased ignition temperatures compared to the atomized powder, while extruded samples were only slightly improved.

\section{Acknowledgment}

Authors wish to thank the Czech Science Foundation (project no. GA19-08937S) and the specific university research MSMT No 21-SVV/2019 for the financial support of this research.

\section{References}

[1] LIU, C., LU, S., FU, Y., ZHANG, H. (2015). Flammability and the oxidation kinetics of the magnesium alloys AZ31, WE43, and ZE10. In: Corrosion Science, Vol. 100, No., pp. 177-185.

[2] SHIH, T.-S., LIU, J.-B., WEI, P.-S. (2007). Oxide films on magnesium and magnesium alloys. In: Materials Chemistry and Physics, Vol. 104, No. 2, pp. 497-504.

[3] AYDIN, D. S., BAYINDIR, Z., HOSEINI, M., PEKGULERYUZ, M. O. (2013). The high temperature oxidation and ignition behavior of $\mathrm{Mg}-\mathrm{Nd}$ alloys part I: The oxidation of dilute alloys. In: Journal of Alloys and Compounds, Vol. 569, No., pp. 35-44.

[4] ZHOU, N., ZHANG, Z., DONG, J., JIN, L., DING, W. (2013). Selective oxidation behavior of an ignition-proof Mg-Y-Ca-Ce alloy. In: Journal of Rare Earths, Vol. 31, No. 10, pp. 1003-1008.

[5] PAN, F., YANG, M., CHEN, X. (2016). A Review on Casting Magnesium Alloys: Modification of Commercial Alloys and Development of New Alloys. In: Journal of Materials Science \& Technology, Vol. 32, No. 12, pp. 1211-1221.

[6] NING, Z. L., ZHAO, X. Y., LUO, A. A., LIU, H. H., LIANG, W. Z., HUANG, Y. J., CAO, F. Y., SUN, J. F. (2017). The melt protection mechanism of an $\mathrm{SO} 2 / \mathrm{CO} 2$ gas mixture for a magnesium-rareearth based alloy. In: Journal of Alloys and Compounds, Vol. 722, No., pp. 101-107.

[7] FAN, J., CHEN, Z., YANG, W., FANG, S., XU, B. (2012). Effect of yttrium, calcium and zirconium on ignition-proof principle and mechanical properties of magnesium alloys. In: Journal of Rare Earths, Vol. 30, No. 1, pp. 74-78.

[8] CHEN, H., CHANG, L., JIE, Y. (2017). Reaction kinetics of $\mathrm{MgF} 2$ powder in air at high temperature. In: Corrosion Science, Vol. 126, No., pp. 121-126.

[9] MONDET, M., BARRAUD, E., LEMONNIER, S., GUYON, J., ALLAIN, N., GROSDIDIER, T. (2016). Microstructure and mechanical properties of AZ91 magnesium alloy developed by Spark Plasma Sintering. In: Acta Materialia, Vol. 119, No., pp. 55-67.
[10] TEKUMALLA, S., GUPTA, M. (2017). An insight into ignition factors and mechanisms of magnesium based materials: A review. In: Materials \& Design, Vol. 113, No., pp. 84-98.

[11] CZERWINSKI, F. (2014). Controlling the ignition and flammability of magnesium for aerospace applications. In: Corrosion Science, Vol. 86, No., pp. 1-16.

[12] GU, X.-N., ZHENG, Y.-F. (2010). A review on magnesium alloys as biodegradable materials. In: Frontiers of Materials Science in China, Vol. 4, No. 2, pp. 111-115.

[13] STAIGER, M. P., PIETAK, A. M., HUADMAI, J., DIAS, G. (2006). Magnesium and its alloys as orthopedic biomaterials: A review. In: Biomaterials, Vol. 27, No. 9, pp. 1728-1734.

[14] AHMADKHANIHA, D., JÄRVENPÄÄ, A., JASKARI, M., SOHI, M. H., ZAREI-HANZAKI, A., FEDEL, M., DEFLORIAN, F., KARJALAINEN, L. P. (2016). Microstructural modification of pure $\mathrm{Mg}$ for improving mechanical and biocorrosion properties. In: Journal of the Mechanical Behavior of Biomedical Materials, Vol. 61, No., pp. 360-370.

[15] KUBÁSEK, J., DVORSKÝ, D., ČAVOJSKÝ, M., VOJTĚCH, D., BERONSKÁ, N., FOUSOVÁ, M. (2017). Superior Properties of $\mathrm{Mg}-4 \mathrm{Y}-3 \mathrm{RE}-\mathrm{Zr}$ Alloy Prepared by Powder Metallurgy. In: Journal of Materials Science \& Technology, Vol. 33, No. 7, pp. 652-660.

[16] WU, G., IBRAHIM, J. M., CHU, P. K. (2013). Surface design of biodegradable magnesium alloys - A review. In: Surface and Coatings Technology, Vol. 233, No., pp. 2-12.

[17] DVORSKÝ, D., KUBÁSEK, J., VOJTĚCH, D. (2015). Hydroxyapatite in Materials for Medical Applications In: Manufacturing Technology, Vol. 15, No. 6, pp. 969-973.

[18] DVORSKY, D., KUBASEK, J., VOJTECH, D. (2017). Corrosion protection of WE43 magnesium alloy by fluoride conversion coating. In: Manufacturing Technology, Vol. 17, No. 4, pp. 440-446.

[19] REN, M., CAI, S., LIU, T., HUANG, K., WANG, X., ZHAO, H., NIU, S., ZHANG, R., WU, X. (2014). Calcium phosphate glass/MgF2 double layered composite coating for improving the corrosion resistance of magnesium alloy. In: Journal of Alloys and Compounds, Vol. 591, No., pp. 34-40.

[20] JO, J.-H., KANG, B.-G., SHIN, K.-S., KIM, H.E., HAHN, B.-D., PARK, D.-S., KOH, Y.-H. (2011). Hydroxyapatite coating on magnesium with MgF2 interlayer for enhanced corrosion resistance and biocompatibility. In: Journal of $M a$ terials Science: Materials in Medicine, Vol. 22, No. 11, pp. 2437-2447. 
[21] SUN, J. E., WANG, J., JIANG, H., CHEN, M., BI, Y., LIU, D. (2013). In vivo comparative property study of the bioactivity of coated $\mathrm{Mg}-3 \mathrm{Zn}-0.8 \mathrm{Zr}$ alloy. In: Materials Science and Engineering: $C$, Vol. 33, No. 6, pp. 3263-3272.

[22] YAN, T., TAN, L., ZHANG, B., YANG, K. (2014). Fluoride Conversion Coating on Biodegradable AZ31B Magnesium Alloy. In: Journal of Materials Science \& Technology, Vol. 30, No. 7, pp. 666-674.

[23] LIU, X., ZHEN, Z., LIU, J., XI, T., ZHENG, Y., GUAN, S., ZHENG, Y., CHENG, Y. (2015). Multifunctional $\mathrm{MgF}$ /Polydopamine Coating on $\mathrm{Mg}$ Alloy for Vascular Stent Application. In: Journal of Materials Science \& Technology, Vol. 31, No. 7, pp. 733-743.

[24] DVORSKY, D., KUBASEK, J., VOJTECH, D. (2018). A new approach in the preparation of biodegradable $\mathrm{Mg}-\mathrm{MgF} 2$ composites with tailored corrosion and mechanical properties by powder metallurgy. In: Materials Letters, Vol. 227, No., pp. $78-81$.
[25] DVORSKÝ, D., KUBÁSEK, J., VOJTĚCH, D., VOŇAVKOVÁ, I., VESELÝ, M., ČAVOJSKÝ, M. (2017). Structure and mechanical characterization of $\mathrm{Mg}-\mathrm{Nd}-\mathrm{Zn}$ alloys prepared by different processes. In: IOP Conference Series: Materials Science and Engineering, Vol. 179, No. 1, pp. 012018.

[26] RALSTON, K. D., BIRBILIS, N., DAVIES, C. H. J. (2010). Revealing the relationship between grain size and corrosion rate of metals. In: Scripta Materialia, Vol. 63, No. 12, pp. 1201-1204.

[27] DVORSKY, D., KUBASEK, J., VOJTECH, D., CAVOJSKY, M. (2016). Structure and mechanical properties of WE43 prepared by powder metallurgy route. In: Manufacturing Technology, Vol. 16, No. 5, pp. 896-902.

DVORSKÝ, D., KUBÁSEK, J., KRISTIANOVÁ, E., VOJTĚCH, D. (2018). Corrosion resistant magnesium-based composite material with $\mathrm{MgF} 2$ continuous network prepared by powder metallurgy. In: Manufacturing Technology, Vol. 18, No. 5, pp. 737-741. 